\title{
Gene Expression of CCAAT/Enhancer-Binding Protein $\delta$ Mediated by Autoregulation Is Repressed by Related Gene Family Proteins
}

\author{
Atsuhiro Tanabe, ${ }^{a}$ Chizumi Kumahara,,${ }^{a}$ Shigehiro Osada, ${ }^{a}$ Tsutomu Nishihara,,${ }^{a}$ and \\ Masayoshi IMAGAWA $* a, b$ \\ Laboratory of Environmental Biochemistry, Graduate School of Pharmaceutical Sciences, Osaka University, ${ }^{a}$ 1-6 \\ Yamada-oka, Suita, Osaka 565-0871, Japan, and Department of Microbial Chemistry, Faculty of Pharmaceutical \\ Sciences, Nagoya City University," 3-1 Tanabe-dori, Mizuho-ku, Nagoya, Aichi 467-8603, Japan. \\ Received June 21, 2000; accepted August 3, 2000
}

CCAAT/enhancer-binding protein $\delta(\mathrm{C} / \mathrm{EBP} \delta)$ transcription factor is rapidly induced at an early stage of acute phase response. We previously reported that this induction was mainly mediated by acute phase response factor/signal transducers and activators of transcription 3 (APRF/STAT3). Furthermore, the high expression level of $\mathrm{C} / \mathrm{EBP} \delta$ is maintained by autoregulation mechanisms through the $\mathrm{C} / \mathrm{EBP} \delta$ binding sites located downstream of C/EBP $\delta$ gene. Thereafter, the expression of C/EBP $\delta$ gene decreases rapidly to the basal level. However, these mechanisms are still unknown. According to both transfection and DNA binding analyses, liver-enriched inhibitory protein (LIP), the shorter form of C/EBP $\beta$ and C/EBP-homologous protein 10 (CHOP10), were found to inhibit $\mathrm{C} / \mathrm{EBP} \delta$ gene expression. DNA binding analysis has further indicated that both LIP and CHOP10 form heterodimers with $\mathrm{C} / \mathrm{EBP} \delta$, and inhibit the binding of C/EBP $\delta$ homodimer to the C/EBP $\delta$ binding sites located downstream of $\mathrm{C} / \mathrm{EBP} \delta$ gene. Taken together, these findings indicated that the maintained expression of C/EBP $\delta$ gene by autoregulation was inhibited and decreased to the basal level as a result of the competition of other $\mathrm{C} / \mathrm{EBP}$ family proteins. Thus, $\mathrm{C} / \mathrm{EBP} \delta$ gene expression is mediated by the gene regulation circuit through the downstream $\mathrm{C} / \mathrm{EBP} \delta$ binding sites.

Key words CCAAT/enhancer-binding protein; CHOP; autoregulation; gene expression; trans-acting factor; transcription

The acute phase response is one of the main defense reactions of animals. During this response, many types of proteins, the so-called acute phase proteins, are induced by different sets of cytokines, including interleukin 1 (IL-1) and IL-6. ${ }^{1,2)}$ These acute phase proteins are classified into two groups: class 1 and class 2 acute phase proteins. ${ }^{1)}$ It is now well known that class 1 genes are activated by CCAAT/enhancer-binding protein (C/EBP) family through $\mathrm{C} / \mathrm{EBP}$ binding sites in their promoter region, whereas class 2 genes are mediated by acute phase response factor/signal transducers and activators of transcription 3 (APRF/STAT3) through the acute phase response element (APRE) ${ }^{1-9)}$ C/EBP family transcription factors consist of several proteins ${ }^{10)} ; \mathrm{C} / \mathrm{EBP} \alpha$, C/EBP $\beta$ (also termed LAP, ${ }^{11)}$ IL6-DBP, ${ }^{12)}$ CRP2, ${ }^{13)}$ AGP/ EBP, ${ }^{14)}$ and NF-IL6, $\left.{ }^{4}\right), \mathrm{C} / \mathrm{EBP} \gamma$ (also termed Ig/EBP-1, ${ }^{15}$ ) GPE1-BP ${ }^{16)}$ ), C/EBP $\delta$ (also termed NF-IL6 $\beta,{ }^{17)}$ CELF, ${ }^{18)}$ CRP $3^{13}$ ), C/EBP $\varepsilon$ (also termed CRP1 ${ }^{13}$ ), and CHOP10 ${ }^{19}$ ) (also termed GADD153 ${ }^{20)}$ ). The main transcription factors for class 1 gene expression are $\mathrm{C} / \mathrm{EBP} \beta$ and $\mathrm{C} / \mathrm{EBP} \delta$ proteins during the acute phase response. ${ }^{10,11,21-26)}$

Since the DNA binding domain, which is the basic region, and the leucine zipper dimerization domain (bZIP) located in the $C$-terminal region of C/EBP family are highly conserved, the sequence preference of C/EBP family is quite similar. ${ }^{27)}$ Therefore, the expression level of each C/EBP seems to be a critical factor, changing dramatically during the acute phase response: mRNA level of $\mathrm{C} / \mathrm{EBP} \alpha$ decreases, and those of $\mathrm{C} / \mathrm{EBP} \beta, \mathrm{C} / \mathrm{EBP} \delta$, and CHOP 10 increase significantly. Interestingly, $\mathrm{C} / \mathrm{EBP} \delta$ is more rapidly and strongly induced than $\mathrm{C} / \mathrm{EBP} \beta$ and CHOP10 in response to lipopolysaccharide (LPS) treatment in the livers of rat ${ }^{28)}$ and mouse. ${ }^{26)}$

We previously reported cloning of the rat $\mathrm{C} / \mathrm{EBP} \delta$ gene and identification of $c i s$-elements modulating $\mathrm{C} / \mathrm{EBP} \delta$ gene expression. ${ }^{29,30)}$ These findings suggested that the $\mathrm{C} / \mathrm{EBP} \delta$ gene expression is induced by APRF/STAT3, which pre-exists and is quickly phosphorylated after stimuli, ${ }^{31)}$ through APRE located in the C/EBP $\delta$ gene promoter. ${ }^{29)}$ Although the transcription regulatory elements exist mainly at the $5^{\prime}$-flanking region, it is reported that the cis-elements at the downstream of the gene mediate the expression of some genes. ${ }^{32-34)}$ Further analyses of $5^{\prime}$ - and $3^{\prime}$-flanking region of $\mathrm{C} / \mathrm{EBP} \delta$ gene have indicated that the high expression level of $\mathrm{C} / \mathrm{EBP} \delta$ mRNA is maintained by binding itself to the regulation sites, $\delta \mathrm{A}$ and $\delta \mathrm{B}$, located at the downstream region $(+3350-+3700 \mathrm{bp})$ of this gene. ${ }^{30)}$ The high level of $\mathrm{C} / \mathrm{EBP} \delta$ gene expression is present for several hours before returning to the basal level. ${ }^{28)}$ The mechanisms of the decrease of $\mathrm{C} / \mathrm{EBP} \delta$ gene expression to the basal level remain to be resolved, however.

C/EBP $\beta$ was originally identified as an activator., ${ }^{4,11,12)}$ Descombes et al. reported that C/EBP $\beta$ mRNA produces an activator (liver-enriched transcriptional activator protein; LAP) and a repressor (liver-enriched inhibitory protein; LIP) using three in-frame ATG codons in an open reading frame by a leaky ribosome scanning mechanism. ${ }^{35)}$ Also, LIP was shown to attenuate the transcriptional stimulation by LAP in substoichiometric amounts, indicating that LIP in low amounts is sufficient for the repression effect. ${ }^{35)} \mathrm{C} / \mathrm{EBP}$-homologous protein 10 (CHOP10) is reported to be a dominant negative inhibitor, since the heterodimer of CHOP10 with other $\mathrm{C} / \mathrm{EBPs}$ is incapable of binding to DNA due to 2 proline substitutions in bZIP of CHOP10. ${ }^{19)}$ Interestingly, C/EBP $\beta$ and CHOP10 expression are delayed; the peak of $\mathrm{C} / \mathrm{EBP} \beta$ and CHOP 10 expression is 2 and $6 \mathrm{~h}$ later than $\mathrm{C} / \mathrm{EBP} \delta$, respectively. ${ }^{28)}$ These findings prompt us to characterize the contribution of $\mathrm{C} / \mathrm{EBP} \beta$ and $\mathrm{CHOP} 10$ to the repression of $\mathrm{C} / \mathrm{EBP} \delta$ expression.

We report here that LIP and CHOP 10 inhibit the $\mathrm{C} / \mathrm{EBP} \delta$ 
gene expression. In addition, transfection analysis indicated that both LIP and CHOP10 reduce transcriptional activity of $\mathrm{C} / \mathrm{EBP} \delta$ through the regulation sites, $\delta \mathrm{A}$ and $\delta \mathrm{B}$, located in the downstream region of this gene. A binding analysis further denoted that both LIP and CHOP10 inhibit the binding of $\mathrm{C} / \mathrm{EBP} \delta$ protein homodimer to the $\delta \mathrm{A}$ and $\delta \mathrm{B}$ sites. Taken together, these findings suggest that the high level expression of $\mathrm{C} / \mathrm{EBP} \delta$ gene maintained by its own product is reduced by LIP and CHOP10, expressions of which are delayed. Thus, $\mathrm{C} / \mathrm{EBP} \delta$ gene expression induced by APRF/STAT3 is highly maintained by the autoregulation mechanism, and then decreased to the basal level through the same regulation elements, the downstream $\mathrm{C} / \mathrm{EBP} \delta$ binding sites.

\section{MATERIALS AND METHODS}

Plasmid Construction The luciferase reporter construct containing +3350 to +3700 at the downstream region of $\mathrm{C} / \mathrm{EBP} \delta$ gene and $-167 /+42 \mathrm{C} / \mathrm{EBP} \delta$ gene promoter was previously described. ${ }^{30)}$ The portion of +3350 to +3700 includes two $\mathrm{C} / \mathrm{EBP} \delta$ binding sites, $\delta \mathrm{A}$ and $\delta \mathrm{B}$. $\mathrm{C} / \mathrm{EBP} \delta$ expression plasmid (MSV-C/EBP $\delta$ ) was kindly provided by Dr. S. L. McKnight. ${ }^{10)}$ LIP expression plasmid, pSCT-LAP (N152) (termed CMV-LIP here), which is a shorter form and lacks $N$-terminal activation domain of C/EBP $\beta$ and CHOP10 expression plasmid, pcDNA1-CHOP10 (termed CMVCHOP10 here) were kind gifts from Drs. U. Schibler and D. Ron, respectively. ${ }^{19,35)}$

For $\mathrm{C} / \mathrm{EBP} \beta$ and $\mathrm{C} / \mathrm{EBP} \delta$ expression in bacteria, the histidine fusion protein system was used. The DNA binding domain (XhoI-DraI fragment) of rat $\mathrm{C} / \mathrm{EBP} \delta$ was cloned into SmaI site of pQE-30 (Qiagen Inc.); pQE-30-C/EBP $\delta$ as described previously. ${ }^{27)}$ For C/EBP $\beta$ expression plasmid, the DNA binding domain (SmaI-SmaI fragment) of rat $\mathrm{C} / \mathrm{EBP} \beta$ (also called SF-B) ${ }^{36)}$ was ligated to $\mathrm{pQE}-32$; $\mathrm{pQE}-32-\mathrm{C} / \mathrm{EBP} \beta$. These plasmids were transformed into M15[pREP4] and used for protein expression in bacteria as described below. CHOP10 was expressed by the GST fusion protein system (Pharmacia Biotech). The EcoRI-EcoRI fragment derived from pcDNA1-CHOP10, including all parts of CHOP10 open reading frame, ${ }^{19)}$ was subcloned into pGEX$3 \mathrm{X}$ expression vector. The recombinant plasmid was transformed into JM109 bacteria.

Cell Culture and Transfection Analysis HepG2 cells, a human hepatoma cell line, were cultured in minimal essential medium (MEM) containing 10\% fetal bovine serum. The cells were then transfected according to the calcium phosphate co-precipitation techniques described by Chen and Okayama. ${ }^{37)}$ One microgram of each luciferase reporter plasmid and $\mathrm{C} / \mathrm{EBP} \delta$ expression plasmid (MSV-C/EBP $\delta$ ) together with $0-2.0 \mu \mathrm{g}$ of LIP expression plasmid (CMV-LIP) or CHOP10 expression plasmid (CMV-CHOP10) were transfected into the cultured cells. The total amount of transfected plasmids was adjusted to $4.5 \mu \mathrm{g}$ with pBluescript $\mathrm{KS}(+)$.

After $40 \mathrm{~h}$ incubation following the transfection, the cells were harvested. The luciferase activity and protein concentrations were then determined with Pikka Gene (Toyo Ink) and a lumiphotometer, and by the method of Bradford, ${ }^{38)}$ respectively. The transfection efficiencies were normalized in accordance with the protein amount. Initial attempt to use several kinds of $\beta$-galactosidase and luciferase expression plasmids as internal controls for the normalization of transfection efficiencies was unsuccessful. As these constructs are harbored by SV40, CMV and RSV promoters, it seems that the binding of endogenous transcription factors is in strong competition with CMV-LIP and CMV-CHOP10 to which they tend to bind. Furthermore, $\beta$-galactosidase and luciferase activities are decreased with increasing amounts of expression plasmids CMV-LIP and CMV-CHOP10. Therefore, we confirmed the transfection efficiencies using pRSVGAL, a $\beta$-galactosidase (lacZ) structural gene controlled by RSV LTR as an external standard. The variation of transfection efficiency was corroborated to be less than $20 \%$. The transfection procedures were performed 7 to 8 times, and typical data are shown.

Production of C/EBP Family Protein in Bacteria The transformants in M15[pREP4] were grown overnight at $30^{\circ} \mathrm{C}$ in LB (Luria-Bertani) medium containing $100 \mu \mathrm{g} / \mathrm{ml}$ ampicillin and $25 \mu \mathrm{g} / \mathrm{ml}$ kanamycin. The culture was then diluted 100 -fold and grown to $\mathrm{OD}_{600} 0.4$; at that time isopropyl- $\beta$-D-thio-galactopyranoside (IPTG) was added to a final concentration of $0.3 \mathrm{~mm}$. Subsequently, the cells were allowed to grow for an additional $4 \mathrm{~h}$, harvested by centrifugation and suspended in $0.1 \mathrm{M}$ HM buffer $(25 \mathrm{~mm}$ HEPES (pH 7.8), $1 \mathrm{~mm}$ dithiothreitol, $12.5 \mathrm{mM} \mathrm{MgCl}_{2}, 20 \%$ glycerol, $0.1 \mathrm{M} \mathrm{KCl}$ ) containing $1 \mathrm{~mm}$ PMSF, $1 \mu \mathrm{g} / \mathrm{ml}$ leupeptin, $1 \mu \mathrm{g} / \mathrm{ml}$ pepstatin $\mathrm{A}$, and $0.3 \mu \mathrm{g} / \mathrm{ml}$ antipain and disrupted by sonication. Following centrifugation at $98000 \mathrm{rpm}$ for $30 \mathrm{~min}$, the supernatant was used for gel-mobility shift analysis.

For CHOP10 expression, the transformants were grown overnight at $30^{\circ} \mathrm{C}$ in $\mathrm{LB}$ medium containing $100 \mu \mathrm{g} / \mathrm{ml}$ ampicillin, inoculated into $100 \mathrm{ml} \mathrm{LB}$ medium, and grown to $\mathrm{OD}_{600} 0.6$, followed by addition of IPTG to a final concentration of $1 \mathrm{~mm}$. The cells were then allowed to grow for an additional $3 \mathrm{~h}$ at $30^{\circ} \mathrm{C}$, harvested and sonicated as described above.

Gel-Mobility Shift Analysis A gel-mobility shift analysis was performed as previously described ${ }^{27)}$ with a slight modification. In brief, $6.25 \mu \mathrm{l}$ of the protein fraction containing $\mathrm{C} / \mathrm{EBP} \delta$ and LIP or CHOP10 was mixed with the same volume of the reaction buffer $(20 \mathrm{~mm}$ Tris- $\mathrm{HCl}(\mathrm{pH} 7.5)$, $10 \%$ glycerol, $2 \mathrm{~mm}$ dithiothreitol, $10 \mathrm{~mm}$ EDTA, $0.5 \mu \mathrm{g}$ of poly $(\mathrm{dI}-\mathrm{dC}), 12.5 \mu \mathrm{g}$ of bovine serum albumin, and $0.2 \mathrm{ng}$ of labeled probe) as well as the competitor. The binding reaction was performed at room temperature for $30 \mathrm{~min}$. When LIP or CHOP 10 was added, $\mathrm{C} / \mathrm{EBP} \delta$ was incubated at room temperature for $45 \mathrm{~min}$ before addition of the reaction buffer. The oligonucleotide sequences of both the probes and competitors are as previously described ${ }^{30)}$ and indicated as follows:

$$
\begin{array}{rlr}
\delta \text { A site: } & \text { 5'-ctagGACTCAATTTCCCAATGTAGCT } & -3^{\prime} \\
& 3^{\prime}-\quad \text { CTGAGTTAAAGGGTTACATCGAgatc }-5^{\prime} \\
\delta \text { B site: } & \text { 5'-ctagATGTAGCTTACTTAATACTTTG } & -3^{\prime} \\
& 3^{\prime}-\quad \text { TACATCGAATGAATTATGAAACgatc }-5^{\prime}
\end{array}
$$

$\delta$ IV site: $5^{\prime}$-ctagTCGTTCCCAGCAGCACT $-3^{\prime}$ $3^{\prime}$ - AGCAAGGGTCGTCGTGAgatc $-5^{\prime}$ 
A.

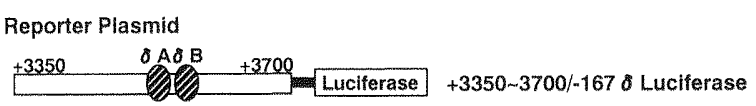

B.

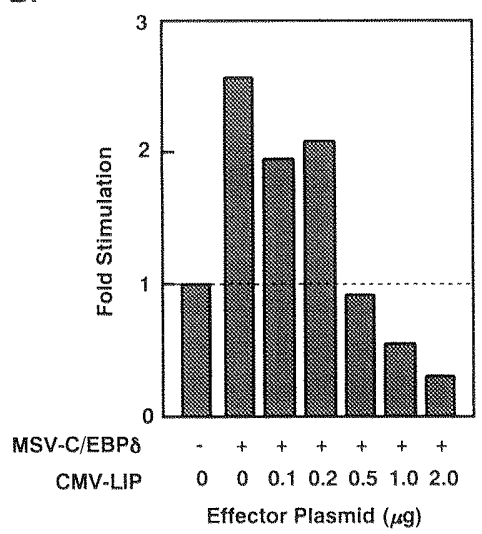

C.

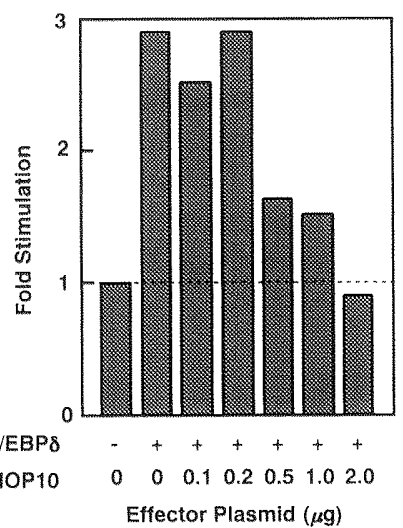

Fig. 1. Effect of LIP and CHOP10 Overexpression on the Activation by C/EBP $\delta$ through C/EBP Binding Sites

HepG2 cells were cotransfected with $1.0 \mu \mathrm{g}$ of reporter plasmid, $0 \mu \mathrm{g}$ or $1.0 \mu \mathrm{g}$ of MSV-C/EBP $\delta$ expression vector, and $0-2.0 \mu \mathrm{g}$ of expression vector, CMV-LIP or CMVCHOPIO. (A) Luciferase construct used as a reporter which contains two C/EBP binding sites; $\delta \mathrm{A}$ and $\delta \mathrm{B}^{301}$ The luciferase activity without MSV-C/EBP $\delta$ expression vector was used as a control value and the fold stimulations by MSV-C/EBP $\delta$ expression vector with increasing amounts of CMV-LIP and CMV-CHOPI0 are shown in panel (B) and (C), respectively.

\section{RESULTS}

LIP and CHOP10 Inhibit Transcriptional Activity of $\mathbf{C} / \mathbf{E B P} \boldsymbol{\delta}$ We have previously reported that $\mathrm{C} / \mathrm{EBP} \delta$ induces its own gene expression by binding to the $\mathrm{C} / \mathrm{EBP} \delta$ binding sequences, $\delta \mathrm{A}$ and $\delta \mathrm{B}$, located downstream of this gene. ${ }^{30)}$ LIP and CHOP10 are the negative regulators of C/EBP family members, and these genes are expressed later than $\mathrm{C} / \mathrm{EBP} \delta$ expression. ${ }^{28)} \mathrm{C} / \mathrm{EBP}$ family proteins are known to form heterodimers with each other, therefore it is possible that the expression of $\mathrm{C} / \mathrm{EBP} \delta$ gene is repressed by heterodimers of $\mathrm{C} / \mathrm{EBP} \delta / \mathrm{LIP}$ and $\mathrm{C} / \mathrm{EBP} \delta / \mathrm{CHOP} 10$ as well as LIP homodimers. ${ }^{35)}$ To examine the effect of LIP and CHOP 10 on the C/EBP $\delta$ gene expression through the $\delta \mathrm{A}$ and $\delta \mathrm{B}$ sites, we performed transfection analysis using the HepG2 cells. As shown in Fig. 1, when the luciferase reporter plasmid including the $\delta \mathrm{A}$ and $\delta \mathrm{B}$ sites was cotransfected with $\mathrm{C} / \mathrm{EBP} \delta$ expression plasmid, the luciferase activities were remarkably stimulated in comparison with the activity without MSV-C/EBP $\delta$ expression vector, consistent with previous results. ${ }^{30)}$ When LIP and CHOP10 expression plasmids were cotransfected at the same time, the luciferase activities were reduced in a dose-dependent manner. The mutant constructs from which the $\delta \mathrm{A}$ and $\delta \mathrm{B}$ sites were deleted did not show any activity rise by the $\mathrm{C} / \mathrm{EBP} \delta$ expression plasmid. Moreover, neither LIP nor CHOP10 expression plasmid affected the luciferase activities (data not shown). These results strongly suggested that LIP and CHOP10 inhibit the transcriptional activity of $\mathrm{C} / \mathrm{EBP} \delta$ gene through the same cis-elements, $\delta \mathrm{A}$ and $\delta \mathrm{B}$, located downstream of this gene, which contribute to the gene's autoregulation.

LIP Protein Binds to the $\boldsymbol{\delta} \mathbf{A}$ and $\delta \mathrm{B}$ Sites We previously reported that C/EBP family proteins recognize similar DNA sequences. ${ }^{27)}$ To determine whether LIP protein binds to the $\delta \mathrm{A}$ and $\delta \mathrm{B}$ sites, we performed a gel-mobility shift analysis using bacterially expressed LIP protein, together
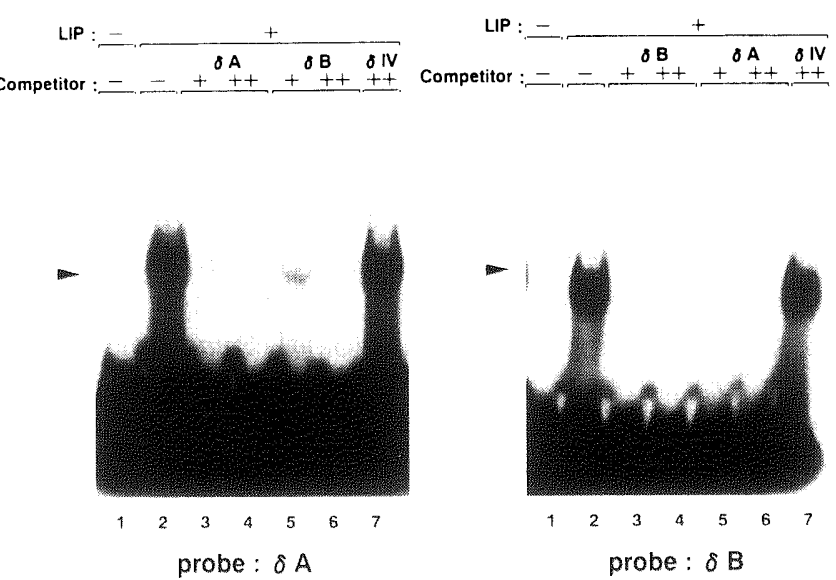

Fig. 2. Gel-Mobility Shift Analysis of C/EBP Binding Sites Located in the Downstream Region of C/EBP $\delta$ Gene Using Bacterially Expressed LIP Protein

Double strand oligonucleotides ( $\delta \mathrm{A}$ and $\delta \mathrm{B}$ ) were used as probes for binding analysis. Each probe ( $\delta \mathrm{A}$ in panel $\mathrm{A}$, and $\delta \mathrm{B}$ in panel $\mathrm{B}$ ) was incubated with bacterially expressed LIP (lanes $2-7$ in both panels). Lane 1 in both panels A and B was controls with bovine serum albumin added 50 -fold $(+)$ or 200 -fold $(++)$ molar excess of nonlabeled oligonucleotides was used for the competition analysis. $\delta$ IV was used as a nonspecific competitor. The competitors added are indicated as $\delta \mathrm{A}, \delta \mathrm{B}$ or $\delta \mathrm{IV}$ above the lanes. Arrowheads indicate the position of the C/EBP $\delta$ homodimer.

with the $\delta \mathrm{A}$ and $\delta \mathrm{B}$ sites as probes. The retarded band was observed when both the $\delta \mathrm{A}$ and $\delta \mathrm{B}$ sites were used as probes and LIP protein was added (Fig. 2, lane 2 in both panels). This band disappeared with the addition of a $50-$ or 200 -fold molar excess of both the non-labeled $\delta \mathrm{A}$ and $\delta \mathrm{B}$ sites (Fig. 2 , lanes 3-6 in both panels). However, 200-fold molar excess of unrelated oligonucleotide $(\delta \mathrm{IV})$ showed no effect on the binding (Fig. 2, lane 7 in both panels). Thus LIP protein binds specifically to both the $\delta \mathrm{A}$ and $\delta \mathrm{B}$ sites.

LIP Inhibits the Binding of C/EBP $\delta$ Homodimer to the $\boldsymbol{\delta} \mathbf{A}$ and $\boldsymbol{\delta} \mathbf{B}$ Sites Next, to determine whether the binding 
A.

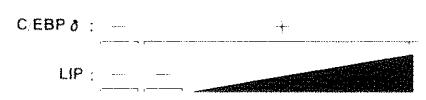

B.
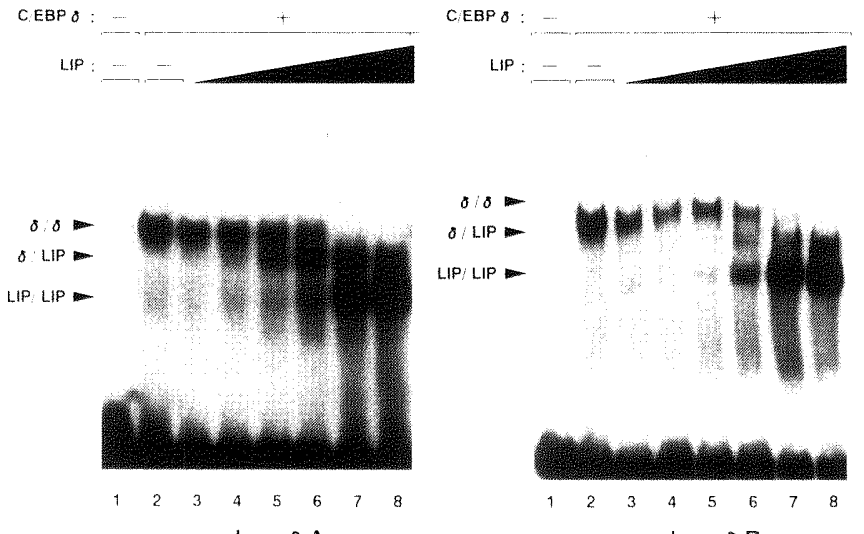

probe: $\delta \mathrm{A}$

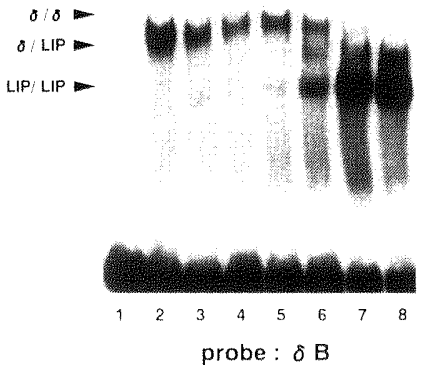

probe : $\delta \mathrm{B}$

Fig. 3. Inhibition of DNA-Binding of $\mathrm{C} / \mathrm{EBP} \delta$ Protein to the $\delta \mathrm{A}$ and $\delta \mathrm{B}$ Sites by Bacterially Expressed LIP Protein

Double strand oligonucleotides, $\delta \mathrm{A}$ and $\delta \mathrm{B}$, were used as probes for binding analysis. Each probe ( $\delta \mathrm{A}$ in panel $\mathrm{A}$, and $\delta \mathrm{B}$ in panel $\mathrm{B}$ ) was incubated with increasing amounts of bacterially expressed LIP $(0-0.3 \mu \mathrm{g}$ protein of crude extract) and a constant amount of C/EBP $\delta$ (lanes $2-8$ in both panels). Lane 1 in both panels A and B was controls with bovine serum albumin added. Arrowheads indicate the positions of $\mathrm{C} / \mathrm{EBP} \delta / \mathrm{C} / \mathrm{EBP} \delta$ homodimer, $\mathrm{C} / \mathrm{EBP} \delta /$ LIP heterodimer and LIP/LIP homodimer as $\delta / \delta, \delta /$ LIP and LIP/LIP, respectively.

of $\mathrm{C} / \mathrm{EBP} \delta$ protein to the $\delta \mathrm{A}$ and $\delta \mathrm{B}$ sites is inhibited by LIP protein, we performed a gel-mobility shift analysis using bacterially expressed $\mathrm{C} / \mathrm{EBP} \delta$ and LIP proteins. The $\mathrm{C} / \mathrm{EBP} \delta$ homodimer band was observed when both the $\delta \mathrm{A}$ and $\delta \mathrm{B}$ sites were used as probes (Fig. 3, lane 2 in both panels). This band disappeared with addition of increasing amounts of LIP protein, revealing the C/EBP $\delta$ /LIP heterodimer and LIP homodimer instead (Fig. 3, lanes $3-8$ in both panels). These results have indicated that LIP protein inhibits the binding of $\mathrm{C} / \mathrm{EBP} \delta$ protein homodimer to the $\delta \mathrm{A}$ and $\delta \mathrm{B}$ sites resulting from heterodimer formation of $\mathrm{C} / \mathrm{EBP} \delta / \mathrm{LIP}$ and/or LIP/LIP homodimer.

CHOP10 Inhibits the Binding of C/EBP $\delta$ Homodimer to the $\delta \mathrm{A}$ and $\delta \mathrm{B}$ Sites It was previously reported that CHOP 10 protein forms heterodimer with $\mathrm{C} / \mathrm{EBP}$ family proteins and inhibits their binding to DNA. ${ }^{19)}$ Therefore, we next determined the effect of CHOP10 protein on the binding of $\mathrm{C} / \mathrm{EBP} \delta$ protein to the $\delta \mathrm{A}$ and $\delta \mathrm{B}$ sites. The band of the $\mathrm{C} / \mathrm{EBP} \delta$ homodimer (Fig. 4, lane 2 in both panels) disappeared with the addition of CHOP 10 protein in a dose-dependent manner (Fig. 4, lanes 3-7 in both panels). These results have suggested that CHOP10 inhibits the binding of $\mathrm{C} / \mathrm{EBP} \delta$ protein homodimer to the $\delta \mathrm{A}$ and $\delta \mathrm{B}$ sites as a result of heterodimer formation.

\section{DISCUSSION}

In the liver of LPS-treated rats, mRNA levels of C/EBPs increased sharply, however, the peak and pattern of C/EBPs expression are different. ${ }^{28)} \mathrm{C} / \mathrm{EBP} \delta$ mRNA expression markedly increased and reached a peak $2 \mathrm{~h}$ post LPS-injection and remained for several hours. On the other hand, the peaks of $\mathrm{C} / \mathrm{EBP} \beta$ and CHOP10 mRNA expressions occurred $4 \mathrm{~h}$ and $8 \mathrm{~h}$ after the treatment, respectively. ${ }^{28)}$ When the cells were treated with IL- 6 , the level of $\mathrm{C} / \mathrm{EBP} \delta$ mRNA increased within $30 \mathrm{~min}^{29)}$ We previously reported that APRF/STAT3 bound to the APRE in the promoter region of

A.
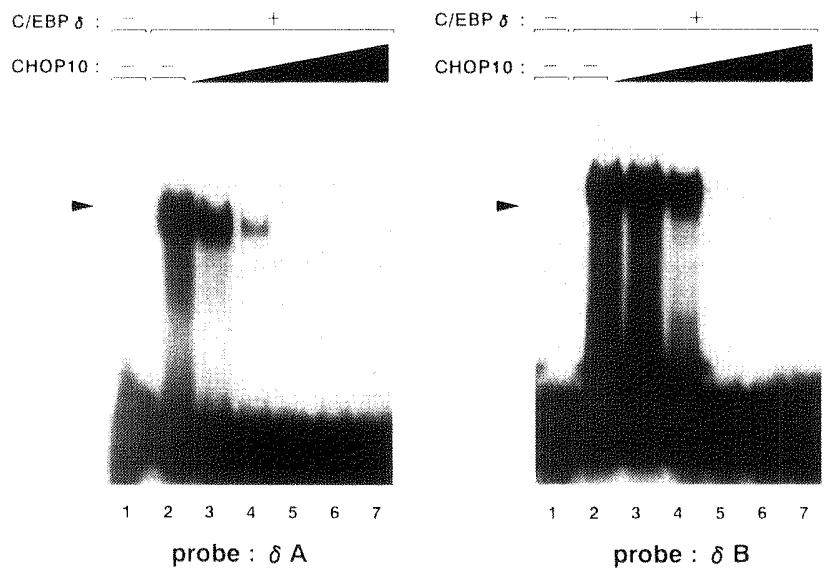

Fig. 4. Inhibition of DNA-Binding of $\mathrm{C} / \mathrm{EBP} \delta$ Protein to the $\delta \mathrm{A}$ and $\delta \mathrm{B}$ Sites by Bacterially Expressed CHOP10 Protein

Double strand oligonucleotides, $\delta \mathrm{A}$ and $\delta \mathrm{B}$, were used as probes for binding analysis. Each probe ( $\delta \mathrm{A}$ in panel $\mathrm{A}$, and $\delta \mathrm{B}$ in panel $\mathrm{B}$ ) was incubated with increasing amounts of bacterially expressed CHOP10 $(0-18.7 \mu \mathrm{g}$ protein of crude extract) and a constant amount of bacterially expressed C/EBP $\delta$ (lanes $2-8$ in both panels). Lane 1 in both panels $\mathrm{A}$ and $\mathrm{B}$ was controls with bovine serum albumin added. Arrowheads indicate the position of the $\mathrm{C} / \mathrm{EBP} \delta$ homodimer.

rat $\mathrm{C} / \mathrm{EBP} \delta$ gene and increased $\mathrm{C} / \mathrm{EBP} \delta$ mRNA expression level at the early stage of acute phase response. ${ }^{29)}$ This expression level is maintained by an autoregulation mechanism: $\mathrm{C} / \mathrm{EBP} \delta$ protein binds to $\mathrm{C} / \mathrm{EBP}$ binding sites at the downstream region of this gene and activates $\mathrm{C} / \mathrm{EBP} \delta$ gene expression. ${ }^{30)}$ This high expression of $\mathrm{C} / \mathrm{EBP} \delta$ gene finally returns to the basal level, although the mechanism of this negative regulation is largely unknown. LIP is one of the $\mathrm{C} / \mathrm{EBP} \beta$ isoforms, and both it and CHOP 10 are known to decrease transcriptional activity of other C/EBPs. ${ }^{19,35)}$ We speculated that LIP and CHOP10, which were induced later than $\mathrm{C} / \mathrm{EBP} \delta$ in the acute phase response, reduced $\mathrm{C} / \mathrm{EBP} \delta$ mRNA expression level. Therefore, we performed cotransfection analyses and DNA binding analyses to resolve this question.

We have shown here that LIP and CHOP10 repressed transcriptional activity mediated by $\mathrm{C} / \mathrm{EBP} \delta$ protein through the $\delta \mathrm{A}$ and $\delta \mathrm{B}$ sites using transfection analysis. When more than $1.0 \mu \mathrm{g}$ of LIP expression plasmid was used, the stimulation fold was lower than 1.0, indicating that LIP/LIP homodimer binds to $\delta \mathrm{A}$ and $\delta \mathrm{B}$ sites and functions as not only the competitor but also the direct repressor. Gel-mobility shift analysis further supported this data; LIP/LIP homodimer was observed when increasing amounts of LIP were added (Fig. 3). CHOP10 forms a heterodimer complex with $\mathrm{C} / \mathrm{EBP} \delta$ and blocks $\mathrm{C} / \mathrm{EBP} \delta$ binding (Fig. 4).

The $\mathrm{C} / \mathrm{EBP} \beta$ mRNA is translated to three isoform types via a leaky ribosome scanning mechanism: two activator types, $\mathrm{LAP}^{\mathrm{FL}}(39 \mathrm{kDa}$ of $\mathrm{C} / \mathrm{EBP} \beta)$ and LAP $(36 \mathrm{kDa}$ of $\mathrm{C} / \mathrm{EBP} \beta$ ) and the inhibitor, LIP. ${ }^{35)}$ It seems that $\mathrm{LAP}^{\mathrm{FL}}$ and LAP as well as LIP bind to the $\delta \mathrm{A}$ and $\delta \mathrm{B}$ sites and also activate transcription. However, $\mathrm{LAP}^{\mathrm{FL}}$ is rarely expressed in the LPS-stimulated mouse liver. ${ }^{39)}$ The LAP is expressed in the control liver, the level of which decreases during acute phase response. On the contrary, the LIP expression increases within $3 \mathrm{~h}$ in the LPS-stimulated mouse liver followed by gradual decrease. ${ }^{39)}$ LIP binds to DNA more tightly than LAP, and only lower amounts of LIP can repress the 


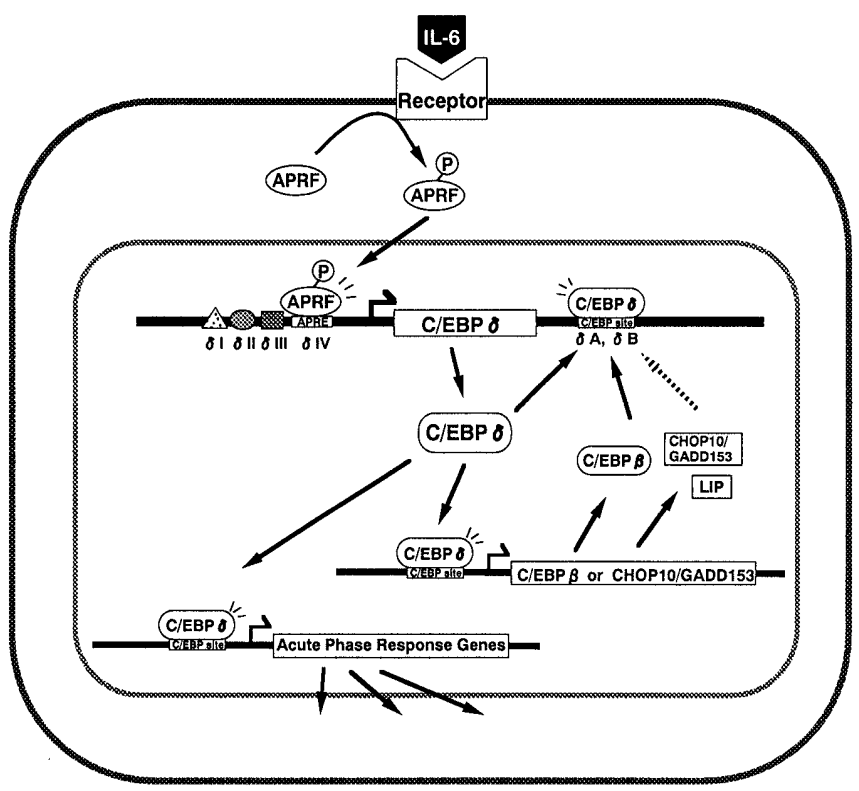

Fig. 5. Proposed Regulation Circuit of $\mathrm{C} / \mathrm{EBP} \delta$ Gene Expression during Acute Phase Response

1) APRF/STAT3 is activated as a result of stimuli-induced phosphorylation. 2) Activated APRF/STAT3 induces C/EBP $\delta$ gene expression. 3) Expressed C/EBP $\delta$ protein induces class 1 acute phase response genes, $\mathrm{C} / \mathrm{EBP} \delta$ gene itself, and perhaps $\mathrm{C} / \mathrm{EBP} \beta$ and CHOP10 genes. 4) Expressed LIP (shorter and inhibitory form $\mathrm{C} / \mathrm{EBP} \beta$ ) and $\mathrm{CHOP} 10$ represses the $\mathrm{C} / \mathrm{EBP} \delta$ gene expression.

transcriptional activity of LAP. ${ }^{35)}$ Therefore, it is likely that LIP is a more important isoform than LAP during the suppression of C/EBP $\delta$ gene in the acute phase response. LAP itself seems to contribute towards the early stage of inflammation stimuli, since LAP transactivation is enhanced by phosphorylation of its activation domain, ${ }^{40)}$ later changing to the inactive form.

Gene promoters of both $\mathrm{C} / \mathrm{EBP} \beta$ and $\mathrm{CHOP} 10$ contain $\mathrm{C} / \mathrm{EBP}$ sites and are regulated by $\mathrm{C} / \mathrm{EBPs}{ }^{28,41)}$ In the acute phase response, $\mathrm{C} / \mathrm{EBP} \beta$ and $\mathrm{CHOP} 10$ gene are expressed later than $\mathrm{C} / \mathrm{EBP} \delta$ expression, perhaps due to the activation by $\mathrm{C} / \mathrm{EBP} \delta$ and $\mathrm{C} / \mathrm{EBP} \beta$ and not by APRF/STAT3, which is readily activated as a result of stimuli-induced phosphorylation. From these findings and our previous reports, the autoregulation circuit of $\mathrm{C} / \mathrm{EBP}$ family proteins is proposed as illustrated in Fig. 5. At the initiation of inflammation stimuli, endogenous APRF/STAT3 is rapidly phosphorylated in response to IL-6 receptor complex formation, and this activated protein binds to APRE located in the $\mathrm{C} / \mathrm{EBP} \delta$ gene promoter. While induced $\mathrm{C} / \mathrm{EBP} \delta$ activates the class 1 acute phase response genes as well as the $\mathrm{C} / \mathrm{EBP} \beta$ and $\mathrm{CHOP} 10$ genes, through the $\mathrm{C} / \mathrm{EBP}$ binding site located in these promoters, $\mathrm{C} / \mathrm{EBP} \delta$ activates itself through the downstream $\mathrm{C} / \mathrm{EBP}$ binding sites and maintains its high level expression. Thereafter, LIP and/or CHOP10 inhibit the binding of $\mathrm{C} / \mathrm{EBP} \delta$ protein to the $\delta \mathrm{A}$ and $\delta \mathrm{B}$ sites and down-regulate $\mathrm{C} / \mathrm{EBP} \delta$ expression. Whereas many kinds of transcription factors contributing to the induction of gene expression were identified and even the up-regulation mechanisms of transcription factors themselves are well characterized in some cases, the final steps of gene expression of up-regulated transcription factors, that is, the steps back to the basal expression have not been well analyzed. The data reported here on the regulation of $\mathrm{C} / \mathrm{EBP} \delta$ gene expression seems to be a good model for the regulation circuit of transcription factors and may help to unravel the complex network for other transcription factors.

Acknowledgements We thank Drs. Steven L. McKnight (The University of Texas Southwestern Medical Center, Dallas, TX, U.S.A.), Ueli Schibler (University of Geneva), and David Ron (New York University Medical Center) for kindly providing MSV-C/EBP $\delta$, pSCT-LAP (N-152), and pcDNA1CHOP10, respectively. This work was supported in part by grants from the Ministry of Education, Science, Sports and Culture, Japan and from the Nissan Science Foundation.

\section{REFERENCES}

1) Baumann H., Prowse K. R., Marinkovic S., Won K. A., Jahreis G. P., Ann. N. Y. Acad. Sci., 557, 280-295 (1989).

2) Poli V., J. Biol. Chem., 273, $29279-29282$ (1998).

3) Heinrich P. C., Castell J. V., Andus T., Biochem. J., 265, 621-636 (1990).

4) Akira S., Isshiki H., Sugita T., Tanabe O., Kinoshita S., Nishio Y., Nakajima T., Hirano T., Kishimoto T., EMBO J., 9, 897-906 (1990).

5) Hattor M., Abraham L. J., Northemann W., Fey G. H., Proc. Natl. Acad. Sci. U.S.A., 87, 2364-2368 (1990).

6) Isshiki H., Akira S., Sugita T., Nishio Y., Hashimoto S., Pawlowski T., Suematsu S., Kishimoto T., New Biol., 3, 63-70 (1991).

7) Hocke G. M., Barry D., Fey G. H., Mol. Cell. Biol., 12, 2282-2294 (1992).

8) Akira S., Kishimoto T., Immunol. Rev., 127, 25-50 (1992).

9) Wegenka U. M., Buschmann J., Lutticken C., Heinrich P. C., Horn F., Mol. Cell. Biol., 13, 276--288 (1993).

10) Cao Z., Umek R. M., McKnight S. L., Genes Dev., 5, 1538-1552 (1991).

11) Descombes P., Chojkier M., Lichtsteiner S., Falvey E., Schibler U., Genes Dev., 4, 1541-1551 (1990).

12) Poli V., Mancini F. P., Cortese R., Cell, 63, 643-653 (1990).

13) Williams S. C., Cantwell C. A., Johnson P. F., Genes Dev., 5, $1553-$ 1567 (1991).

14) Chang C. J., Chen T. T., Lei H. Y., Chen D. S., Lee S. C., Mol. Cell. Biol., 10, 6642-6653 (1990).

15) Roman C., Platero J. S., Shuman J., Calame K., Genes Dev., 4, 1404 1415 (1990).

16) Nishizawa M., Wakabayashi-Ito N., Nagata S., FEBS Lett., 282, $95-$ 97 (1991).

17) Kinoshita S., Akira S., Kishimoto T., Proc. Natl. Acad. Sci. U.S.A., 89, 1473-1476 (1992).

18) Kageyama R., Sasai Y., Nakanishi S., J. Biol. Chem., 266, 1552515531 (1991).

19) Ron D., Habener J. F., Genes Dev., 6, 439-453 (1992).

20) Fornace A. J., Jr., Nebert D. W., Hollander M. C., Luethy J. D., Papathanasiou M., Fargnoli J., Holbrook N. J., Mol. Cell. Biol., 9, 41964203 (1989).

21) Birkenmeier E. H., Gwynn B., Howard S., Jerry J., Gordon J. I., Landschulz W. H., McKnight S. L., Genes Dev., 3, 1146-1156 (1989).

22) Diehl A. M., Yang S. Q., Hepatology, 19, 447-456 (1994).

23) Baumann H., Morella K. K., Campos S. P., Cao Z., Jahreis G. P., J. Biol. Chem., 267, 19744-19751 (1992).

24) Ray A., Ray B. K., Mol. Cell. Biol., 14, 4324-4332 (1994).

25) Lin F. T., Lane M. D., Proc. Natl. Acad. Sci. U.S.A., 9, 8757-8761 (1994).

26) Alam T., An M. R., Papaconstantinou J., J. Biol. Chem., 267, 50215024 (1992).

27) Osada S., Yamamoto H., Nishihara T., Imagawa M., J. Biol. Chem., 271, 3891-3896 (1996)

28) Sylvester S. L., Rhys C. M. ap, Luethy-Martindale J. D., Holbrook N. J., J. Biol. Chem., 269, 20119-20125 (1994).

29) Yamada T., Tobita K., Osada S., Nishihara T., Imagawa M., J. Biochem., 121, 731-738 (1997).

30) Yamada T., Tsuchiya T., Osada S., Nishihara T., Imagawa M., Biochem. Biophys. Res. Commun., 242, 88-92 (1998).

31) Akira S., Nishio Y., Tanaka T., Inoue M., Matsusaka T., Wang X. J., 
Wei S., Yoshida N., Kishimoto T., Ann. N. Y. Acad. Sci., 762, 15-27 (1995).

32) Beck I., Ramirez S., Weinmann R., Caro J., J. Biol. Chem., 266, 15563-15566 (1991).

33) Perez-Albuerne E. D., Schatteman G., Sanders L. K., Nathans D., Proc. Natl. Acad. Sci. U.S.A., 90, 11960-11964 (1993).

34) Hyder S. M., Stancel G. M., J. Steroid Biochem. Mol. Biol., 48, 6979 (1994).

35) Descombes P., Schibler U., Cell, 67, 569-579 (1991).

36) Imagawa M., Osada S., Koyama Y., Suzuk T. I., Hirom P. C., Diccianni M. B., Morimura S., Muramatsu M., Biochem. Biophys. Res. Com- mun., 179, 293-300 (1991).

37) Chen C., Okayama H., Mol. Cell. Biol., 7, 2745-2752 (1987).

38) Bradford M. M., Anal. Biochem., 72, 248-254 (1976).

39) An M. R., Hsieh C. C., Reisner P. D., Rabek J. P., Scott S. G., Kuninger D. T., Papaconstantinou J., Mol. Cell. Biol., 16, 2295-2306 (1996).

40) Trautwein C., Caelles C., Geer P. van der, Hunter T., Karin M., Chojkier M., Nature (London), 364, 544-547 (1993).

41) Chang C. J., Shen B. J., Lee S. C., DNA Cell Biol., 14, 529-537 (1995). 